\title{
CHANGES IN OXIDATIVE STRESS INTENSITY IN BLOOD OF TUMOR-BEARING RATS FOLLOWING DIFFERENT MODES OF ADMINISTRATION OF RHENIUM-PLATINUM SYSTEM
}

\author{
K. L. SHAMELASHVILI', N. I. SHTEMENKO', I. V. LEUS ${ }^{3}$, \\ S. O. BABIY', O. V. SHTEMENKO \\ ${ }^{1}$ SE "Dnipropetrovsk Medical Academy" of Health Ministry of Ukraine; \\ ${ }^{2}$ Palladin Institute of Biochemistry, National Academy of Sciences of Ukraine, Kyiv; \\ ${ }^{3}$ University of Oklahoma, Oklahoma-city, USA; \\ ${ }^{4}$ Institute of Gastroenterology, National Academy of Medical Sciences \\ of Ukraine, Dnipropetrovsk; \\ ${ }^{5}$ Ukrainian State University of Chemical Technology, Dnipropetrovsk; \\ e-mail: shamelashvili@rambler.ru
}

Effects of the different modes of administration of dichlorotetra- $\mu$-isobutyratodirhenium(III) - I - (in water solution, liposomes, nanoliposomes and together with cisplatin - in the rhenium-platinum system) on the intensity of lipid peroxidation (LP) in blood plasma and the activity of the erythrocyte antioxidant enzymes were investigated on the model of tumor growth. A decrease in the concentration of TBA-active substances caused by dirhenium compounds was shown to be independent of the administration mode and the extent of the tumor growth inhibition. I was four-times more effective in inhibition of the LP burst than any known antioxidant. I induced the increasing activity of erythrocyte superoxide dismutase and decreasing activity of catalase. In vitro experiments with native superoxide dismutase, the interaction of $\boldsymbol{I}$ with following activation of the active center of the enzyme was confirmed and the superoxide dismutase activity of $\boldsymbol{I}$ was shown, that may contribute to the enhancement of the enzyme activity in vivo. The cluster rhenium compounds may be promising nontoxic potent antioxidants capable of deactivating superoxide radicals.

Key words: lipid peroxidation, oxidative stress, Guerin's carcinoma, catalase, superoxide dismutase, cisplatin.

I $\mathrm{n}$ our previous work it was shown that cluster rhenium(III) compounds with organic ligands exhibit pronounced anticancer and antiradical activities, particularly in combination with platinum compounds (Re-Pt system) [1, 2]. The most studied among them is dichlorotetra- $\mu$ isobutyratodirhenium(III) $\mathrm{Re}_{2}\left(\mathrm{i}-\mathrm{C}_{3} \mathrm{H}_{7} \mathrm{COO}\right)_{4} \mathrm{Cl}_{2}-(\mathrm{I})$, which both individually and as a part of the Rhenium-Platinum system has anticancer, hepato- and nephroprotective activity. Compound I has several structural features (Fig. 1), which might be responsible for the above indicated properties: a) binuclear clustering of rhenium atoms; as the main component of the molecule is characterized by low toxicity; b) quadrupole bond, which is responsible for antiradical and antioxidant properties; c) chlorine atoms, which are able to interact with polar molecules; g) branched alkyl groups and their symmetrical arrangement that provide hydrophobic interactions.
One of the directions of further studies of the compound I and other cluster rhenium compounds is to find the optimal modes of administration of $\mathbf{I}$ alone or in the Re-Pt system, at which both an effective inhibition of tumor growth and suppression of the intensity of the free radical burst that accompany tumor growth can be achieved.

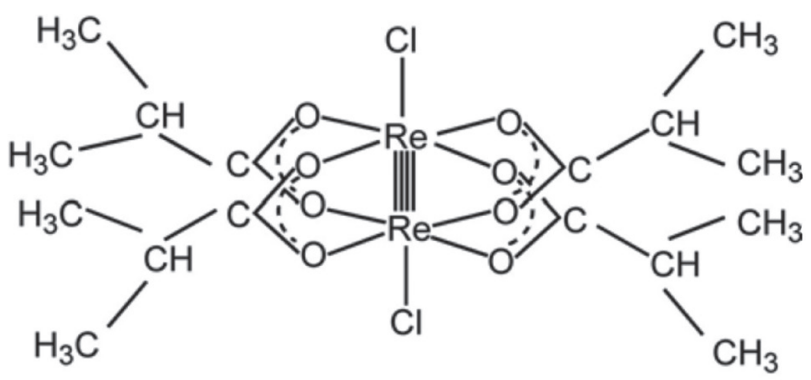

Fig. 1. Dichlorotetra- $\mu$-isobutyratodirhenium(III) (I) 
Experiments in vitro showed that the rhenium compounds with isobutyrate ligands, which are dicarboxylate structural type, in cis- and trans-configurations interact with erythrocyte SOD and change protein conformation. It was found that cis-dicarboxylate dirhenium(III) exhibits superoxide dismutase activity that is not inherent in trans-dicarboxylatdirhenium(III) [3]. Therefore, the study of the influence of rhenium compound with isobutyrate ligands of tetracarboxylate type on SOD molecule in experiments in vivo and in vitro is a consequential continuation of previous studies that may highlight the problem of direct interaction of $\mathbf{I}$ with the SOD molecule.

Thus, the aim of this work was to study the effect of $\mathbf{I}$ at various modes of administration on basic parameters of oxidative stress in blood of rats with Guerin's carcinoma and on the activity of native SOD in vitro.

\section{Materials and Methods}

In our research we studied cluster compound dichlorotetra- $\mu$-isobutyratodirhenium(III) $\operatorname{Re}_{2}$ (i$\left.\mathrm{C}_{3} \mathrm{H}_{7} \mathrm{COO}\right)_{4} \mathrm{Cl}_{2}-($ I) (Fig. 1) synthesized in the Ukrainian State University of Chemical Technology [1]. Liposome [I]lip, nanoliposome [I]nl forms of $\mathbf{I}$ and solid nanoparticles loaded with $\mathbf{I}$ and the Re-Pt system with various ratios of the components inside lipid capsule [I $+\mathrm{cPt}(4: 1)]$ lip, [I $+\mathrm{cPt}(4: 1)] \mathrm{nl},[\mathbf{I}+\mathrm{cPt}$ (4: 1)] np, [I+cPt (4:2)] nl, [I+cPt (4:2)] were prepared according to [2].

Wistar rats weighing 100-150 g maintained in standard vivarium conditions were used in the experiments. Rats without tumor were control group. All animal experiments were performed in accordance with the rules of the European Convention for the Protection of Vertebrate Animals used for Experimental and Other Scientific Purposes (Strasbourg, 1986). Tumor growth was modeled by transplantation of 20\% suspension of Guerin's carcinoma cells (T8) in solution to healthy rats (group T8) according to [2]. The compounds of rhenium and platinum were administered by various modes:

mode 1 - administration of the compound $\mathbf{I}$ alone. The compound $\mathbf{I}$ in solution (sln), in the form of normal liposome (lip) 5-10 $\mu \mathrm{m}$, in the form of nanoliposoms (nl) and solid nanoparticles (np) 10$100 \mathrm{~nm}$ (group T8+[I] sln, T8+[I] lip, T8+[I] nl, $\mathrm{T} 8+[\mathbf{I}] \mathrm{np}$, respectively) were administered intraperitoneally ten times at a dose of $7 \mu \mathrm{mol} / \mathrm{kg}$ for 21 days with an interval of one day starting from the $3^{\text {rd }}$ day after cancer cells transplantation. Administration of I was also conducted per os ten times at the same dose in the form of solid nanoparticles $10-100 \mathrm{~nm}$ starting from the $3^{\text {rd }}$ day after cancer cells transplantation (group $\mathrm{T} 8+[\mathbf{I}] \mathrm{np}($ per os));

mode 2 - administration of the Re-Pt system components, wherein cisplatin was administered once in aqueous solution, and rhenium compound was administered ten times in liposome form or in the form of nanoparticles with a final molar ratio of rhenium compound:platinum 4:1. A single intraperitoneal injection of cisplatin solution $(\mathrm{cPt})$ at a dose of $1.75 \mu \mathrm{mol} / \mathrm{kg}$ was performed on the $9^{\text {th }}$ day after tumor transplantation, and intraperitoneal administration of I was conducted at the same doses and modes (as described above for mode 1), groups: $\mathrm{T} 8+\mathrm{cPt}+[\mathbf{I}]$ lip, $\mathrm{T} 8+\mathrm{cPt}+[\mathbf{I}] \mathrm{nl}, \mathrm{T} 8+\mathrm{cPt}+[\mathbf{I}] \mathrm{np}, \mathrm{T} 8+\mathrm{cPt}+[\mathbf{I}] \mathrm{np}$ (per os);

mode 3 - combined use of the Re-Pt system in the form of mixed nanoliposomes and nanoparticles, where both cytostatics were inside lipid nanocapsules. Intraperitoneal administration of nanoliposomes and nanoparticles 100-150 nm loaded with $\mathbf{I}$ and cPt in molar ratios of $4: 1$ and $4: 2$ was conducted starting from the $3^{\text {rd }}$ day after tumor transplantation in the amount of $7 \mu \mathrm{mol} / \mathrm{kg}$ of rhenium compound and the corresponding amount of cisplatin; groups: $\mathrm{T} 8+[\mathbf{I}+\mathrm{cPt}(4: 1)] \mathrm{nl}, \mathrm{T} 8+[\mathbf{I}+\mathrm{cPt}(4: 1)] \mathrm{np}$, $\mathrm{T} 8+[\mathbf{I}+\operatorname{cPt}(4: 2)] \mathrm{nl}, \mathrm{T} 8+[\mathbf{I}+\mathrm{cPt}(4: 1)] \mathrm{np}$ (per os).

Animals were decapitated under chloroform anesthesia on the $21^{\text {st }}$ day. Tumor was removed and weighed. Content of the compounds that react with thiobarbituric acid (TBA-active compounds) in blood plasma, the activities of superoxide dismutase (SOD), catalase (CAT) and glutathione peroxidase (GP) in erythrocyte hemolysates were examined using methods [4-7]. The antioxidant effectiveness $(\mathrm{E} \%)$ was calculated as a ratio of the concentration of TBA-active compounds in blood in the experiment with administration of antioxidant to the concentration of TBA-active compounds upon the pathology in the experiments without antioxidant administration.

In vitro studies were performed using $\mathrm{Cu}, \mathrm{Zn}$ SOD from bovine erythrocytes (Sigma-Aldrich, USA), $0.056 \mathrm{mg} / \mathrm{ml}$. Fluorescence was measured in phosphate buffer $\mathrm{pH} 7.4$ using spectrofluorimeter Shimadzu RF-5301 PC (Japan), slit width EX: $10.0 \mathrm{~nm}$ and EM: $10.0 \mathrm{~nm}$, excitation wavelength $290 \mathrm{~nm}$ [8]. The effect of the compound I in a molar ratio of 1(SOD):10(I) was studied immediately after mixing. SOD activity in the presence of $\mathbf{I}$ and SOD- 
like activity of $\mathbf{I}$ in vitro were determined on the xanthine-xanthine oxidase system expenditure using 19160 SOD Determination Kit (Sigma-Aldrich Chemie $\mathrm{GmbH}$ ). Measurements were carried out every minute during a period of $5 \mathrm{~min}$ after the addition of xanthine oxidase solution at $25^{\circ} \mathrm{C}$ using spectrophotometer Shimadzu UV-1601 UV-visible at $440 \mathrm{~nm}$. We registered the changes in absorbance $\left(\mathrm{A} \cdot 10^{-2}\right)$ as the differences between the absorbance every minute and the absorbance of the mixture at the beginning of the experiment, i.e., absorbance values growth. All measurements were carried out in triplicate and presented as means with standard errors. The results were statistically processed using the Student's $t$-test. Differences in values were considered statistically significant at $P \leq 0.05$.

\section{Results and Discussion}

The chosen model of tumor growth - Guerins carcinoma (T8) - is characterized by intense growth and reaches a weight of 50-65 $\mathrm{g}$ (which is $20-40 \%$ of rat body weight) by the $21^{\text {st }}$ day after transplantation of cancer cells (Table 1).

In this group we observed a significant increase (more than 6-fold) in the concentration of TBAactive compounds, which indicates intensification of the lipid peroxidation (LP) process, inherent in "radical burst" in this model. Upon the action of $\mathrm{cPt}$ (group $\mathrm{cPt}$ ) the tumor weight by the $21^{\text {st }}$ day was 3.5fold less than that in the group T8. The intensity of LP in the blood plasma of these animals was also reduced almost 2-fold due to inhibition of the tumor growth.

When compound I was administered intraperitoneally and per os by mode 1 , the tumor weight was reduced to $30-50 \%$, i.e. much less than upon administration of cPt. However, inhibition of the LP intensity was more pronounced than in the group upon administration of $\mathrm{cPt}$ (in some experimental groups was almost twice more).

Ta b le 1. Tumor weight, tumor inhibition index and concentration of TBA-active compounds in the plasma of the experimental animals, $n=8-10$

\begin{tabular}{|c|c|c|c|}
\hline Experimental group & Tumor weight, $g$ & Inhibition, $\%$ of $\mathrm{T} 8$ & TBA content, mol/1 \\
\hline Control & - & - & $7,69 \pm 0,38$ \\
\hline $\mathrm{T} 8$ & $63.27 \pm 3.16$ & - & $52.88 \pm 2.64^{\#}$ \\
\hline $\mathrm{cPt}$ & $17.72 \pm 0.89 * *$ & $71.99 \pm 3.60$ & $21.16 \pm 1.06^{\#, *}$ \\
\hline \multicolumn{4}{|c|}{ Mode 1} \\
\hline $\mathrm{T} 8+[\mathbf{I}] \operatorname{sln}$ & $50.34 \pm 3.08^{*, \neq}$ & $20.44 \pm 1.02 *$ & $19.48 \pm 0.99^{*, \#}$ \\
\hline $\mathrm{T} 8+[\mathbf{I}]$ lip & $46.33 \pm 2.31^{*, *}$ & $26.77 \pm 1.34^{*}$ & $17.54 \pm 0.88^{*, \#}$ \\
\hline $\mathrm{T} 8+[\mathbf{I}] \mathrm{nl}$ & $45.64 \pm 2.15^{*}$ & $27.86 \pm 1.39 *$ & $19.50 \pm 0.90^{* \# \#}$ \\
\hline $\mathrm{T} 8+[\mathbf{I}] \mathrm{np}$ & $34.68 \pm 2.46^{*}$ & $45.18 \pm 2.26^{*}$ & $12.44 \pm 0.60^{* *, \#}$ \\
\hline $\mathrm{T} 8+\mathbf{I}$ np (per os) & $29.80 \pm 1.49 *$ & $52.90 \pm 2.65^{*}$ & $11.54 \pm 0.58^{* *, \#}$ \\
\hline \multicolumn{4}{|c|}{ Mode 2} \\
\hline $\mathrm{T} 8+\mathrm{cPt}+[\mathbf{I}]$ lip & $0.28 \pm 0.01 * * *$ & $99.56 \pm 4.98^{* * *}$ & $5.12 \pm 0.26 * *$ \\
\hline $\mathrm{T} 8+\mathrm{cPt}+[\mathbf{I}] \mathrm{nl}$ & $1.98 \pm 0.11^{* * *}$ & $96.87 \pm 4.84^{* * *}$ & $11.90 \pm 0.62 * *, \#$ \\
\hline $\mathrm{T} 8+\mathrm{cPt}+[\mathbf{I}] \mathrm{np}$ & $0.93 \pm 0.05^{* * *}$ & $98.53 \pm 4.93^{* * *}$ & $8.65 \pm 0.43 * *$ \\
\hline $\mathrm{T} 8+\mathrm{cPt}+[\mathbf{I}] \mathrm{np}($ per os $)$ & $0.21 \pm 0.01^{* * *}$ & $99.67 \pm 4.98^{* * *}$ & $12.02 \pm 0.64 * *, \#$ \\
\hline \multicolumn{4}{|c|}{ Mode 3} \\
\hline $\mathrm{T} 8+[\mathbf{I}+\mathrm{cPt}(4: 1)] \mathrm{nl}$ & $1.38 \pm 0.07 * * *$ & $97.82 \pm 4.89^{* * *}$ & $7.53 \pm 0.38 * *$ \\
\hline $\mathrm{T} 8+[\mathbf{I}+\mathrm{cPt}(4: 1)] \mathrm{np}$ & $2.39 \pm 0.12^{* * *}$ & $96.22 \pm 4.81 * * *$ & $12.72 \pm 0.64 * *, \#$ \\
\hline $\mathrm{T} 8+[\mathbf{I}+\mathrm{cPt}(4: 1)] \mathrm{np}($ per os $)$ & $27.31 \pm 1.37 * *$ & $56.84 \pm 2.84^{* *}$ & $31.09 \pm 1.55 *, \#$ \\
\hline $\mathrm{T} 8+[\mathbf{I}+\mathrm{cPt}(4: 2)] \mathrm{nl}$ & $18.13 \pm 0.90^{* *}$ & $71.35 \pm 3.57^{* *}$ & $10.90 \pm 0.55 * *, \#$ \\
\hline $\mathrm{T} 8+[\mathrm{I}+\operatorname{cPt}(4: 2)] \mathrm{np}$ & $30.03 \pm 1.51^{*}$ & $52.54 \pm 2.63^{*}$ & $26.44 \pm 1.22 * \#$ \\
\hline
\end{tabular}

${ }^{\#} P<0.05$ relative to the control group; $* P<0.05 ;{ }^{* *} P<0.01 ; * * * P<0.001$ relative to the group $\mathrm{T} 8 ;{ }^{*} P<0.05$ relative to the group $\mathrm{T} 8+[\mathbf{I}] \mathrm{np}$ 
It should be noted that various modes of administration of equal amounts of $\mathbf{I}$ differ in their effectiveness in tumor growth inhibition: the administration of liposomal forms or solution resulted in less tumor inhibition compared to administration of solid nanoparticles loaded with $\mathbf{I}$. These findings point out an importance of further research using solid nanoparticles loaded with anticancer agents. It is known that this drug formulation is suitable for storage and administration of medicines [9]. It should also be noted that the liposome size does not affect the parameters of efficiency of tumor growth inhibition and oxidative stress in these experiments, when compared groups $\mathrm{T} 8+[\mathbf{I}] 1$ and $\mathrm{T} 8+[\mathbf{I}] \mathrm{nl}$. Thus, it was shown that the compound $\mathbf{I}$ administered alone to tumor-bearing rats in various forms exhibited moderate antitumor activity and ability to inhibit oxidative stress, regardless of the form of administration. So, the use of solid nanoparticles in therapy is promising in a search for new classes of antitumor agents.

Administration of the components of Re-Pt system by mode 2 demonstrates efficient, almost complete inhibition of the tumor growth. The tumor growth in the most of experimental animals was significantly inhibited regardless of the modes of the system components administration. In our previous works, effectiveness of the Re-Pt system as antitumor agent was shown on many cluster rhenium compounds, and, in our opinion, it might be caused, by a synergistic or additive mechanism of interaction between the platinum, rhenium compounds and DNA. It should be noted that administration of the components of the Re-Pt system by mode 2 led not only to a significant inhibition of tumor growth but also to a significant reduction (normalization) in concentrations of the LP products.

The obtained results for Re-Pt system efficiency became an impetus for development of new nanoforms, namely nanoliposomes and solid nanoparticles, which would contain both cytostatics - $\mathrm{cPt}$ and I inside lipid nanocapsule. Such mixed and solid nanoparticles were synthesized and characterized [2]. Administration of the combined Re-Pt system in mixed nanoliposomes and nanoparticles to the experimental animals by the mode 3 was also effective, in terms of both antitumor and antioxidant activities, except for experiments, where the amount of cisplatin within the nanocapsules was increased and where the mixed nanoparticles were administered per os. In our view, the possibility to change the content of cytostatics inside nanocapsules is a significant step toward nanotechnology and combined therapy in the cancer treatment.

It is known that the concentration of the TBAactive compounds in the blood plasma is an important biochemical marker that reflects the intensity of the whole body LP - a process that is a consequence of membrane lipid oxidation by reactive oxygen species, excessive formation of which occurs under many pathological conditions $[10,11]$. Administration of the antioxidants significantly reduces the oxidative stress intensity in the organisms [12].

If application of known antioxidants lead to a maximum 1.5-2-fold reduction in the blood LP intensity at various pathologies, the efficiency of the compound I in LP inhibition is much higher (4fold) than the efficiency of known antioxidants. The mechanism of action of known antioxidants lies in direct interaction with radicals via conjugated $\pi$-bonds (e.g., vitamins A, C, E) to form stable particles, which inhibit radical chain reaction. Quadrupole bond of cluster direnium fragment easily binds the electrons of free radicals on low-energy $\delta$-antibonding molecular orbital. Known organometallic compounds also exhibit antioxidant effects, however, these effects are realized via $\pi$-unsaturated ligands, of e.g. the polyphenol or flavonoid nature [14]. The rhenium compounds with quadrupole bond represent a new class of highly effective $\delta$-antioxidants that, along with their non-toxicity, makes them promising drugs.

Red blood cells, or erythrocytes, are the most numerous and specialized cells in the organisms. The main function of red blood cells is to transport oxygen and carbon dioxide. During erythropoiesis, erythrocytes lose nucleus, ribosomes, mitochondria, and thus the ability to cell division, protein synthesis and oxidative processes inherent in mitochondria [15]. Due to their physiological role, the red blood cells are permanently affected by endogenous oxidative stress: the auto-oxidation of oxyhemoglobin to methemoglobin generates superoxide radical $\left(\mathrm{O}_{2}{ }^{-}\right)$, which is the main source of free radicals in erythrocyte. Oxidative stress, which occurs at pathologies, can damage erythrocytes as well as other biological molecules of the organism [10]. Normal erythrocytes have a reducing activity, which is 250 -fold greater than their oxidation potential [13]. However, when the intensity of oxidative stress is increased, erythrocyte antioxidant system lacks defense, and the cell becomes the storage and carrier of extracellu- 
lar superoxide anion-radical and hydrogen peroxide, which can be transported through the anion channel, or freely penetrate the membrane, respectively.

Erythrocyte antioxidant system mainly involves activities of: $\mathrm{Cu}, \mathrm{Zn}-\mathrm{SOD}$, which maintains the concentration of superoxide anion at 10-13 mol/l; CAT, which decomposes hydrogen peroxide to water and oxygen (activities of these enzymes in erythrocyte much higher than in the other body tissues except for liver); glutathione peroxidase (GP), which catalyzes the same reaction as CAT. Changes in the activity of these enzymes lead to an imbalance of redox status of cells and consequently of the whole organism. Thus, a study of enzymes of erythrocyte antioxidant system upon various pathologies gives an insight into the redox status of the whole organism. The role of erythrocyte SOD and CAT as antioxidant enzymes maintaining redox status of the whole body is confirmed by the fact that administration of these proteins as drugs leads to antioxidant protection of the whole body [11]. For example, administration of the liposomes loaded with SOD and CAT to rats with oxygen intoxication (100\% oxygen) significantly increased their life span [16]. Discovery of the antioxidant, anti-inflammatory, anti-carcinogenic effect of these proteins has triggered an intensive search for their low molecular biomimetics based on organometallic compounds [17]. Namely these organometallic compounds are the basis for the creation of such mimetics since SOD and CAT are metalloproteids.

Numerous studies on the activity of erythrocyte antioxidant enzymes upon various pathologies, summarized in the review [10], have indicated that the high intensity of oxidative stress in the body leads to a decrease in the activity of erythrocyte SOD and CAT, as well as to the imbalance in action of antioxidant enzymes. It has been found that high concentrations of the free radical compounds inactivate SOD, CAT and GP. For example, in the SOD molecule under the influence of significant concentrations of hydroxyl radical, histidine 118 is oxidized to oxo-2 histidine in the active site that, in turn, leads to complete enzyme inactivation [18].

In our experiments, development of oxidative stress (group T8) resulted in a decrease in the erythrocytic SOD activity (by 14\%) and CAT activity (by $59 \%$ ) (Table 2) compared with the control.

Administration of cisplatin (group $\mathrm{cPt}$ ) led to a significant increase in the SOD activity (about 3 -fold) and a decrease in the CAT activity (by a fac- tor of 1.5) compared to control, and an increase in the SOD and CAT activities compared to the group T8. Administration of $\mathbf{I}$ led to increasing of the SOD activity compared to the control group (2-3.1fold), compared to the tumor-carrier group (2.1-3.3fold), and the cisplatin group (by $15-27 \%$ for groups $\mathrm{T} 8+[\mathbf{I}+\operatorname{cPt}(4: 1)] \mathrm{nl}, \mathrm{T} 8+[\mathbf{I}+\mathrm{cPt}(4: 1)] \mathrm{np})$. Administration of $\mathbf{I}$ increased the CAT activity 1.5-2.3-fold compared to the group T8 and max. 1.5-fold compared to the cisplatin group, although did not reach to the control values.

The data on the different effects of Re and $\mathrm{Pt}$ compounds on the SOD and CAT activities can be explained by their different effects on erythropoiesis. In particular, during carcinogenesis, inhibition of the Nrf-2 (eritroid derivative nuclear factor) that regulates the expression of antioxidant enzymes has been shown [11]; rhenium cluster compounds support the erythropoiesis process upon the neoplasm development [20]; cisplatin suppresses erythropoiesis; the red blood cells, short-lived but with high amount of SOD, are formed.

On the other hand, the organometallic compounds may directly interact with erythrocyte antioxidant enzymes. However, it is known that cisplatin, at direct interaction, inactivates SOD and CAT enzymes by binding thiol residues of cysteine [20]. At the same time, direct activation of the rhenium compounds is possible [3].

Given the calculations based on our data and carried out according to [21], we can say that parameters of the control group correspond to zone I of oxidative stress intensity [22]. Parameters of the groups, in which the studied compounds were administered by mode 2, correspond to zone II. Parameters of the groups $\mathrm{cPt}$ and $\mathrm{T} 8$ correspond to zones III and IV, respectively (Table 3 ).

According to this classification, there are four zones in hormetic (from the Greek hormesis - rapid motion) oxidative stress curve, which differ in the stress intensity and response of enzyme systems to an increase in the concentration of inducers of free radical burst. The first zone, to which, perhaps, the control group refers, is characterized by basal oxidative stress.

The second zone is characterized by higher intensity of oxidative stress and activation, or moderate inactivation of the antioxidant enzymes. The groups, in which the Re-Pt system was administered by mode 2 , may be associated with this zone. The fourth zone, which is characterized by a high 
Table 2. The activity of erythrocyte antioxidant enzymes in the experimental animals (\% of control)

\begin{tabular}{lcc}
\hline \multicolumn{1}{c|}{ Experimental group } & SOD activity, \% & CAT activity, \% \\
\hline Control & 100.00 & 100.00 \\
$\mathrm{~T} 8$ & $85.92 \pm 5.20^{\#}$ & $41.08 \pm 2.05^{\#}$ \\
$\mathrm{cPt}$ & $291.49 \pm 6.62^{\#, *}$ & $66.70 \pm 3.34^{\#, *}$ \\
& Mode 1 & \\
$\mathrm{~T} 8+[\mathbf{I}] \mathrm{sln}$ & $264.15 \pm 7.18^{* *, \#}$ & $84.16 \pm 3.96^{*, \#}$ \\
$\mathrm{~T} 8+[\mathbf{I}]$ lip & $292.13 \pm 9.15^{* *, \#}$ & $91.84 \pm 4.59^{*}$ \\
$\mathrm{~T} 8+[\mathbf{I}] \mathrm{nl}$ & $294.00 \pm 10.24^{* *, \#}$ & $90.46 \pm 5.02^{*}$ \\
$\mathrm{~T} 8+[\mathbf{I}] \mathrm{np}$ & $262.15 \pm 8.15^{* *, \#}$ & $94.46 \pm 4.32^{*}$ \\
$\mathrm{~T} 8+\mathbf{I} \mathrm{np}($ per os $)$ & $198.32 \pm 7.14^{*, \#}$ & $86.18 \pm 4.02^{*, \#}$ \\
& Mode 2 & \\
$\mathrm{~T} 8+\mathrm{cPt}+[\mathbf{I}]$ lip & $290.14 \pm 8.04^{* *, \#}$ & $64.16 \pm 3.18^{*, \#}$ \\
$\mathrm{~T} 8+\mathrm{cPt}+[\mathbf{I}] \mathrm{nl}$ & $280.15 \pm 7.56^{* *, \#}$ & $68.14 \pm 3.26^{*, \#}$ \\
$\mathrm{~T} 8+\mathrm{cPt}+[\mathbf{I}] \mathrm{np}$ & $246.18 \pm 6.16^{* *, \#}$ & $82.14 \pm 4.12^{*, \#}$ \\
$\mathrm{~T} 8+\mathrm{cPt}+[\mathbf{I}] \mathrm{np}($ per os $)$ & $218.14 \pm 5.84^{* *, \#}$ & $80.46 \pm 4.18^{*, \#}$ \\
& Mode 3 & \\
$\mathrm{~T} 8+[\mathbf{I}+\mathrm{cPt}(4: 1)] \mathrm{nl}$ & $318.46 \pm 11.56^{* *, \#}$ & $72.18 \pm 4.12^{*, \#}$ \\
$\mathrm{~T} 8+[\mathbf{I}+\mathrm{cPt}(4: 1)] \mathrm{np}$ & $306.15 \pm 8.14^{* *, \#}$ & $84.18 \pm 5.46^{*, \#}$ \\
$\mathrm{~T} 8+[\mathbf{I}+\mathrm{cPt}(4: 1)] \mathrm{np}($ per os $)$ & $242.14 \pm 7.18^{* *, \#}$ & $90.32 \pm 6.28^{*}$ \\
$\mathrm{~T} 8+[\mathbf{I}+\mathrm{cPt}(4: 2)] \mathrm{nl}$ & $261.18 \pm 8.14^{* *, \#}$ & $62.16 \pm 4.14^{*, \#}$ \\
$\mathrm{~T} 8+[\mathbf{I}+\mathrm{cPt}(4: 2)] \mathrm{np}$ & $274.15 \pm 8.45^{* *, \#}$ & $60.12 \pm 3.96^{\#}$ \\
\hline$\# P<0.05$ r & & \\
\hline
\end{tabular}

${ }^{\#} P<0.05$ relative to control group; ${ }^{*} P<0.05 ; * * P<0.01 ; * * * P<0.001$ relative to group T8

Ta ble 3. Oxidative stress parameters of the blood of experimental animals given the oxidative stress intensity

\begin{tabular}{l|c|c|c|c}
\hline \multirow{2}{*}{ Parameters of redox status } & \multicolumn{4}{|c}{ Zone of oxidative stress intensity } \\
\cline { 2 - 5 } & I low & II low & III moderate & IV high \\
\hline Content of TBA-active & 7.69 & $5.12-12.02$ & 21.16 & 52.82 \\
compounds, mmol/1 (\%) & $(100)$ & $(66.57-156.31)$ & $(275.16)$ & $(686.87)$ \\
SOD activity, \% & 100 & $218.14-290.14$ & 291.49 & 85.92 \\
CAT activity, \% & 100 & $64.16-82.14$ & 66.70 & 41.08 \\
Group & Control & Administration & cPt (conditionally) & T8 \\
& & by mode 2 & & \\
\hline
\end{tabular}

intensity of oxidative stress and inactivation of the antioxidant enzymes, probably includes T8 group. The cPt group, according to the indicated above parameters, can be associated with the zone III only conditionally since, increased SOD activation was observed there. Other studied groups can be also associated with the zone II or III only conditionally. Thus, the obtained data on the intensity of oxidative stress and the activity of the antioxidant enzymes can be explained only partially by the relationship between the concentration of stress inducer and the effect.

Interpretation of the data on the CAT activity is complicated by the fact that red blood cells have another enzyme (GP) decomposing hydrogen peroxide. Since the CAT activity decreased in the blood of 


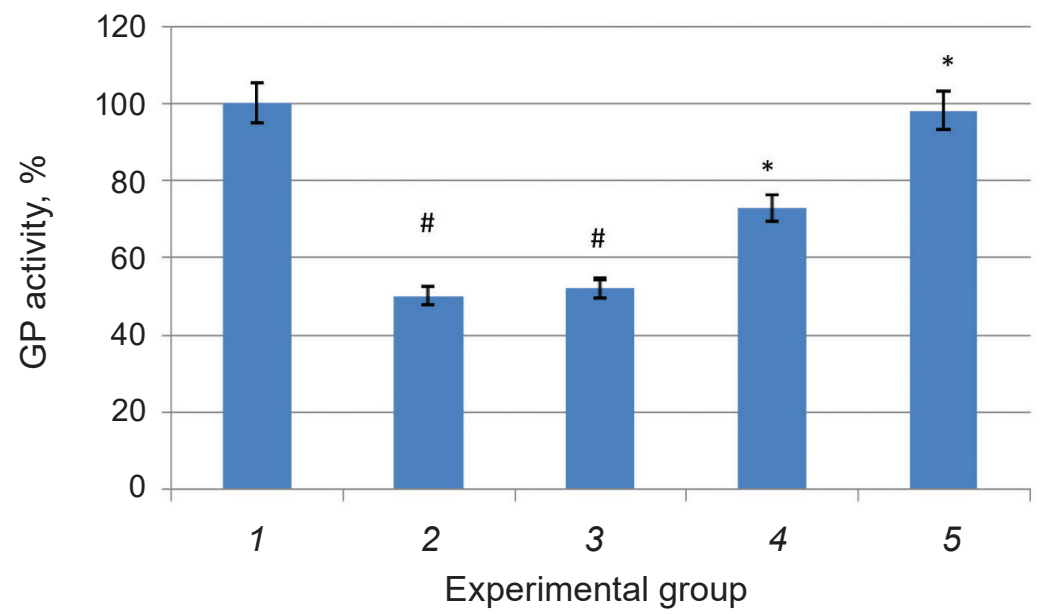

Fig. 2. Erythrocyte glutathione peroxidase activity in some groups of the experimental animals: 1 -control; $2-T 8 ; 3-c P t ; 4-T 8+c P t+[\mathbf{I}]$ nl; $5-T 8+[\mathbf{I}+c P t(4: 1)]$ nl. ${ }^{*} P<0.05$ relative to control, $* P<0.05$ relative to group $T 8$

rats of all experimental groups compared with the control, additional analysis of the GP activity was carried out in some groups (Fig. 2).

During the growth of transplanted Guerin's carcinoma, GP activity reduced by $50 \%$ compared to control (Fig. 2). Causes of a decrease in this enzyme activity is probably the same as for other antioxidant enzymes. Administration of $\mathrm{cPt}$ did not affect the enzyme activity compared to the tumor-bearing rats, despite a significant antitumor effect of cPt. Since, GP is glutathione-dependent enzyme, it should be noted that $\mathrm{cPt}$ directly interacts with glutathione [23] and binds specifically with selen and thiol groups at the GP active center [13] that results in the enzyme inactivation. Probably, that is why the level of the GP activity did not increase, although a significant inhibition of tumor growth was observed.

Upon administration of the Re-Pt system (modes 2 and 3) an increase in the enzyme activity by $22-77 \%$ compared with the group T8 was observed. Thus, normalizing of the redox-status of erythrocytes under the action of $\mathbf{I}$ can be explained by both SOD activation that led to reduction of the superoxide anion concentration and GP activation that led to reduction of the hydrogen peroxide concentration. Activation of the erythrocyte antioxidant enzymes and decrease in the ROS concentration caused lowering of the LP intensity in the cell and the whole organism.

Activation of the erythrocyte SOD upon administration of certain rhenium compounds, we explained by their SOD-like activity, or by possible interaction with the SOD molecule and following by changes in apoenzyme conformation and a corresponding increase in the reaction rate in the active site of the enzyme [3]. The possibility to apply the same explanation for the compound I was the next stage of this study.

The addition of $\mathbf{I}$ to the SOD solution resulted in a change in tyrosine fluorescence intensity (Fig. 3).

We chose fluorescence of tyrosine for establishing the possible interaction between $\mathbf{I}$ and SOD, since only this amino acid residue is a fluorophore, and the SOD molecule does not contain tryptophan [24]. During the reaction of SOD with $\mathbf{I}$ in the ratio of $1: 10$ we observed the main peak with $\lambda_{\max }=321 \mathrm{~nm}$

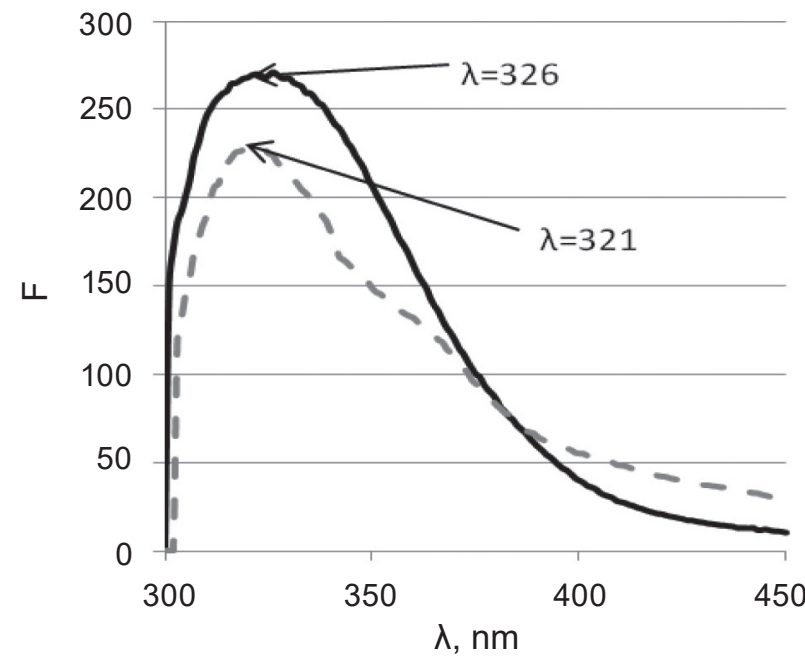

Fig. 3. Fluorescence spectrum for SOD (-) and $S O D$ with $I$ (_ _ ) in a molar ratio of $1: 10$ 
Ta b le 4. Changes in absorption $\left(A \cdot 10^{-2}\right)$ of the reaction mixture upon the addition of SOD, SOD with $\boldsymbol{I}$ in ratio of $1: 10$ in xanthine-xanthineoxidase system $(M \pm m ; n=3)$

\begin{tabular}{c|c|c|c}
\hline Time, $\min$ & SOD & SOD $+\mathbf{I}$ & I \\
\hline 1 & $4.34 \pm 0.25$ & $1.42 \pm 0.23$ & $10.62 \pm 2.22$ \\
2 & $10.42 \pm 0.61$ & $9.17 \pm 0.49$ & $9.43 \pm 1.94$ \\
3 & $16.40 \pm 0.93$ & $17.83 \pm 1.45$ & $8.15 \pm 2.13$ \\
4 & $22.21 \pm 1.86$ & $24.62 \pm 1.83$ & $14.66 \pm 3.36$ \\
5 & $27.77 \pm 2.48$ & $30.36 \pm 4.14$ & $26.92 \pm 5.12$ \\
\hline
\end{tabular}

(blue shift compared to the native protein) with the longwave shoulder $\lambda=360 \mathrm{~nm}$. This indicates that compound I directly interact with the protein molecule. Similar changes in the SOD fluorescence were observed when direnium dicarboxylates were added [3]. It allows us to state that interaction with SOD occurs by means of the structural element which exists in all of these compounds namely, quadrupole bond $\mathrm{Re}-\mathrm{Re}$, and the shift of the fluorescence peak corresponds to a change in polarity around the chromophore molecule (in this case, Tyr-108). Fluorescence quenching was $11.4 \%$, which is much less than that for the cis-dicarboxylates.

We also studied the effect of the compound I on the activity of SOD as well as the SOD-like activity of I in the xanthine-xanthineoxidase system (Table 4).

It is known that in such experiments the intensity of the superoxide dismutase reaction is inversely proportional to the rate of the absorption change. The addition of SOD+I mixture into xanthinexanthineoxidase system did not lead to significant changes in the enzyme activity compared to native SOD, except a decrease (by $67.28 \%$ ) within $1^{\text {st }}$ min of the experiment, indicating the short-term SOD activation in the presence of $\mathbf{I}$. Previously, it was shown that rhenium cis-diisobutyrate had a similar effect [3]. So, we concluded that the binding of $\mathbf{I}$ to the protein occurs a significant distance from the active site, and the presence of $\mathbf{I}$ in long-last experiment did not significantly affect the SOD activity.
The study of SOD-like activity of I showed that this compound exhibited pronounced activity in the reaction with superoxide ion starting from the $2^{\text {nd }} \min$ of the experiment compared to the native enzyme and dichlorotetra- $\mu$-isobutyratodirhenium(III) [3]. Absorption of $\mathbf{I}$ on the $3^{\text {rd }}$ min of the experiments was 2 -fold lower than that of native enzyme indicating significant SOD-like activity. SOD-like activity of $\mathbf{I}$ at the end of the experiments was close to the activity of native SOD. Similar SOD-like activity was shown for copper compounds [25]. Thus, a significant increase in the SOD activity in the blood of tumor-bearing rats upon administration of I can be partially explained by SOD-like activity of this compound and activation of the SOD molecule upon its interaction with $\mathbf{I}$.

Thus, regulation of oxidative stress in blood of tumor-bearing rats by claster rhenium compounds occurs mainly owing to a unique quadrupole bond capable of quenching of the free radical reaction, the positive effect on erythropoiesis, the direct interaction with antioxidant enzymes and their intrinsic SOD-like activity. It should be noted that a search for low-molecular SOD-mimetics among the rhenium compounds is a promising direction in researches.

\section{Acknowledgement}

Authors express their deep gratitude to $\mathrm{PhD}$ D. E. Kitova for the preparation and analysis of liposomes and nanoparticles. We are also grateful for the partial financial support of COST Action CM1105. 
ЗМІНИ ІНТЕНСИВНОСТІ

ОКСИДАТИВНОГО СТРЕСУ КРОВІ

ЩУРІВ-ПУХЛИНОНОСІїВ ЗА

ВВЕДЕННЯ СИСТЕМИ РЕНІЙПЛАТИНА РІЗНИМИ СПОСОБАМИ

К. Л. Шамелашвілі', Н. І. Штеменко I. В. Леус ${ }^{3}$ С. О. Бабій , О. В. Штеменко

${ }^{1}$ ДУ «Дніпропетровська медична академія» MO3 України;

${ }^{2}$ Інститут біохімії ім. О. В. Палладіна

НАН України, Київ;

${ }^{3}$ Університет Оклахоми, Оклахома-сіті, США;

${ }^{4} Д У ~ «$ Інтитут гастроентерології НАМН

України», Дніпропетровськ;

${ }^{5}$ Український державний хіміко-технологічний університет, Дніпропетровськ;

e-mail: shamelashvili@rambler.ru

Досліджено вплив способу введення дихлоротетра- $\mu$-ізобутиратодиренію(III) - I (у водному розчині, ліпосомах, наноліпосомах, твердих наночастинках і разом з цисплатином у системі реній-платина) на інтенсивність процесу пероксидного окислення ліпідів (ПОЛ) плазми крові та активність ензимів антиоксидантного захисту еритроцитів на моделі пухлинного росту. Встановлено зменшення вмісту ТБК-активних продуктів плазми за введення $\mathbf{I}$ щурам-пухлиноносіям незалежно від способу та інтенсивності гальмування пухлини. Показано ефективність зниження (у чотири рази) гасіння ПОЛ сполукою $\mathbf{I}$, що значно перевищує ефективність відомих антиоксидантів. Виявлено збільшення активності супероксиддисмутази та зменшення активності каталази еритроцитів за введення I різними способами у порівнянні 3 контролем. В експериментах in vitro 3 нативною супероксиддисмутазою доведено факт взаємодії ензиму 3 I із наступною активацією активного центру та виявлено супероксиддисмутазну активність I, що може бути певним внеском у підвищення активності ензиму in vivo. Показано перспективність використання кластерних сполук ренію в медицині як нетоксичних ефективних антиоксидантів, здатних до дезактивації супероксидного радикала.

К л ю ч о в і с л о в а: пероксидне окислення ліпідів, оксидативний стрес, кластерна сполука ренію, карцинома Герена, каталаза, супероксиддисмутаза, цисплатин.

\section{ИЗМЕНЕНИЕ ИНТЕНСИВНОСТИ \\ ОКСИДАТИВНОГО \\ СТРЕССА КРОВИ КРЫС- \\ ОПУХОЛЕНОСИТЕЛЕЙ ПРИ ВВЕДЕНИИ СИСТЕМЫ РЕНИЙ- ПЛАТИНА РАЗНЫМИ СПОСОБАМИ}

К. Л. Шамелашвили', Н. И. Штеменко ${ }^{2}$, И. В. Леус, С. О. Бабий, А. В. Штеменко

${ }^{1} Г У$ «Днепропетровская медицинская академия» МЗ Украины;

Институт биохимии им. А. В. Палладина НАН Украины, Киев;

${ }^{3}$ Университет Оклахомы, Оклахома-сити, США; ${ }^{4} Г У$ «Институт гастроэнтерологии

НАМН Украины, Днепропетровск;

${ }^{5}$ Украинский государственный химико-

технологический университет, Днепропетровск; e-mail:shamelashvili@rambler.ru

Исследовано влияние способа введения дихлоротетра- $\mu$-изобутиратодирения(III) - I (в водном растворе, липосомах, нанолипосомах, твердых наночастицах и вместе с цисплатином в системе рений-платина) на интенсивность процесса пероксидного окисления липидов (ПОЛ) плазмы крови и активность энзимов антиоксидантной защиты эритроцитов на модели опухолевого роста. Показано снижение содержания ТБК-активных продуктов в плазме при введении I опухоленосителям независимо от способа и интенсивности торможения роста опухоли. Продемонстрирована эффективность (четырехкратное снижение) гашения ПОЛ веществом I, что значительно превышает эффективность известных антиоксидантов. Выявлено увеличение активности эритроцитарной супероксиддисмутазы и снижение активности эритроцитарной каталазы при введении I разными способами по сравнению с контролем. В экспериментах in vitro с нативной супероксиддисмутазой доказано взаимодействие энзимов с I c последующей активацией активного центра и обнаружена супероксиддисмутазная активность I, что может быть определенным вкладом в повышение активности энзима in vivo. Показана перспективность использования кластерных соединений рения как нетоксичных эффективных антиоксидантов, способных дезактивировать супероксидный радикал. 
Кл ю че вы е сл о в а: пероксидное окисление липидов, оксидативный стресс, кластерное соединение рения, карцинома Герена, каталаза, супероксиддисмутаза, цисплатин.

\section{References}

1. Shtemenko N, Collery P, Shtemenko A. Dichlorotetra-mu-Isobutyratodirhenium(III): enhancement of cisplatin action and RBCstabilizing properties. Anticancer Res. 2007; 27(4B): 2487-2492.

2. Li Z, Shtemenko NI, Yegorova DY, Babiy SO, Brown AJ, Yang T, Shtemenko AV, Dunbar KR. Liposomes loaded with a dirhenium compound and cisplatin: preparation, properties and improved in vivo anticancer activity. J Liposome Res. 2015; 25(1): 78-87.

3. Leus IV, Shamelashvili KL, Skoryk OD, Tretyak SIu, Golichenko OA, Shtemenko OV, Shtemenko NI. Antioxidant and antitumor activity of dirhenium dicarboxylates in animals with Guerin carcinoma. Ukr Biokhim Zhurn. 2012; 84(3): 72-81. (In Ukrainian).

4. Andreeva LI, Kozhemiakin LA, Kishkun AA. Modification of the method of determining lipid peroxidation in a test using thiobarbituric acid. Lab Delo. 1988; (11): 41-43. (In Russian).

5. Kostiuk VA, Potapovich AI, Kovaleva ZhV. A simple and sensitive method of determination of superoxide dismutase activity based on the reaction of quercetin oxidation. Vopr Med Khim. 1990; 36(2): 88-91. (In Russian).

6. Koroliuk MA, Ivanova LI, Mayorova IG, Tokarev VE. A method of determining catalase activity. Lab Delo. 1988; (1):16-19. (In Russian).

7. Yablonsky SV, Filinska AM. Evaluation of hepatotoxicity of novel maleimide derivative with cytostatic activity and its effect on peroxidation process and antioxidant system in the liver. Ukr Biokhim Zhurn. 2009; 81(5): 8392. (In Ukrainian).

8. Leus IV, Klenina IO, Zablotska KA, Golichenko OA, Shtemenko OV, Shtemenko NI. Interaction of serum albumins with cluster rhenium compounds of cis- and transconfiguration. Biopolym Cell. 2011; 27(6): 465471.

9. Seeta Rama Raju G, Benton L, Pavitra E, Yu JS. Multifunctional nanoparticles: recent progress in cancer therapeutics. Chem Commun (Camb). 2015; 51(68): 13248-13259.
10. Nikolic-Kokic A, Blagojevic D, Spasic M. Complexity of free radical Metabolism in human Erythrocytes. J Med Biochem. 2010; 29(3): 189195.

11. Hybertson BM, Gao B, Bose SK, McCord JM. Oxidative stress in health and disease: the therapeutic potential of Nrf2 activation. Mol Aspects Med. 2011; 32(4-6): 234-246.

12. Ratnam DV, Ankola DD, Bhardwaj V, Sahana DK, Kumar MN. Role of antioxidants in prophylaxis and therapy: A pharmaceutical perspective. J Control Release. 2006; 113(3): 189-207.

13. Ognjanović BI, Pavlović SZ, Maletić SD, Zikić RV, Stajn AS, Radojicić RM, Saicić ZS, Petrović VM. Protective influence of vitamin E on antioxidant defense system in the blood of rats treated with cadmium. Physiol Res. 2003; 52(5): 563-570.

14. Jungwirth $U$, Kowol CR, Keppler BK, Hartinger CG, Berger W, Heffeter P. Anticancer activity of metal complexes: involvement of redox processes. Antioxid Redox Signal. 2011; 15(4): 1085-1127.

15. Spasojevic I. Electron paramagnetic resonance A powerful tool of medical biochemistry in discovering mechanisms of disease and treatment prospects. J Med Biochem. 2010; 29(3): 175-188.

16. Turrens JF, Crapo JD, Freeman BA. Protection against oxygen toxicity by intravenous injection of liposome-entrapped catalase and superoxide dismutase. J Clin Invest. 1984; 73(1): 87-95.

17. Muscoli C, Cuzzocrea S, Riley DP, Zweier JL, Thiemermann C, Wang ZQ, Salvemini D. On the selectivity of superoxide dismutase mimetics and its importance in pharmacological studies. Br J Pharmacol. 2003; 140(3): 445-460.

18.Uchida K, Kawakishi S. Identification of oxidized histidine generated at the active site of $\mathrm{Cu}, \mathrm{Zn}$ superoxide dismutase exposed to $\mathrm{H}_{2} \mathrm{O}_{2}$. Selective generation of 2-oxo-histidine at the histidine 118. J Biol Chem. 1994; 269(4): 2405-2410.

19. Voronkova YS, Babiy SO, Ivans'ka LV, Shtemenko OV, Shtemenko NI. Antioxidant properties of cluster rhenium compounds and their effect on erythropoiesis of rats with guerin carcinoma. Ukr Biochem J. 2015; 87(1): 99-108. (In Ukrainian).

20. Weidt SK, Mackay CL, Langridge-Smith PR, Sadler PJ. Platination of superoxide dismutase 
with cisplatin: tracking the ammonia ligands using Fourier transform ion cyclotron resonance mass spectrometry (FT-ICR MS). Chem Commun (Camb). 2007; (17): 1719-1721.

21. Lushchak VI. Classification of oxidative stress based on its intensity. EXCLI J. 2014; 13: 922937.

22. Lushchak VI. Dissection of the hormetic curve: analysis of components and mechanisms. Dose Response. 2014; 12(3): 466-479.

23. Khynriam D, Prasad SB. Changes in endogenous tissue glutathione level in relation to murine ascites tumor growth and the anticancer activity of cisplatin. Braz J Med Biol Res. 2003; 36(1): 53-63.
24. Ferreira ST, Stella L, Gratton E. Conformational dynamics of bovine $\mathrm{Cu}, \mathrm{Zn}$ superoxide dismutase revealed by time-resolved fluorescence spectroscopy of the single tyrosine residue. Biophys J. 1994; 66(4): 1185-1196.

25. González-Alvarez M, Alzuet G, Borrás J, Castillo Agudo L, Montejo-Bernardo JM, GarcíaGranda S. Development of novel copper(II) complexes of benzothiazole- $\mathrm{N}$-sulfonamides as protective agents against superoxide anion. Crystal structures of $[\mathrm{Cu}(\mathrm{N}-2-(4-$ methylbenzothiazole)benzenesulfonamidate) (2)(py)(2)] and [Cu( N-2-(6-nitrobenzothiazole) naphthalenesulfonamidate)(2)(py)(2)]. $\quad J \quad B i o l$ Inorg Chem. 2003; 8(1-2): 112-120.

Received 14.12.2015 